\title{
Książki szkolne opublikowane w Wydawnictwie M. Arcta stosowane w praktyce dydaktyczno-wychowawczej w Drugiej Rzeczypospolitej
}

W okresie Drugiej Rzeczypospolitej w praktyce edukacyjnej funkcjonowały liczne książki szkolne (podręczniki, książki pomocnicze), zakwalifikowane do użytku szkolnego dla uczniów szkół powszechnych i średnich ogólnokształcących przez Ministerstwo Wyznań Religijnych i Oświecenia Publicznego, które implikują treść kształcenia z obszaru edukacji ekologicznej. Należy podkreślić, że w latach 1918-1939 nie było osobnego podręcznika z zakresu edukacji ekologicznej, ale problematykę realizowano hasłowo w ramach lekcji z przyrody i geografii. Celem artykułu jest prezentacja książek szkolnych z przyrody i geografii (m.in. podręczników, pogadanek przyrodniczych i krajoznawczych, atlasów, opowiadań) opublikowanych przez Wydawnictwo M. Arcta, które służyły dydaktyczno-wychowawczą pomocą w procesie hasłowo realizowanej edukacji ekologicznej w szkołach powszechnych i średnich ogólnokształcących w okresie Drugiej Rzeczypospolitej. Niektóre z tych dzieł wyszły jeszcze przed odzyskaniem niepodległości w 1918 roku.

Wśród książek szkolnych wydano pogadanki przyrodnicze Maksymiliana Heilperna, któremu Ministerstwo Wyznań Religijnych i Oświecenia Publicznego powierzyło prace nad programem biologii w szkołach powszechnych i średnich ogólnokształcących. Dzięki pogadankom Heilpern popularyzował nauki przyrodnicze, zwracał uwagę dzieci na wartość środowiska przyrody, np. na oczyszczanie powietrza przez rośliny ${ }^{1}$. Wydawnictwo M. Arcta opublikowało również kilka prac Konrada Chmielewskiego, w których Chmielewski zawarł malownicze ekspresje

* Dr, Uniwersytet Kardynała Stefana Wyszyńskiego w Warszawie, Wydział Nauk Pedagogicznych, Katedra Historii Wychowania i Dziejów Oświaty, 01-938 Warszawa, ul. Wóycickiego 1/3.

1 Por. M. Heilpern, Pogadanki o tajemnicach przyrody, Część pierwsza: Wiadomości wstępne o świecie. Wydanie piąte z 75 rysunkami w tekście. Wydawnictwo M. Arcta, Warszawa 1917, s. 239. 
opisów przyrody Tatr oraz wyjątki z poezji sławiącej piękno polskiej przyrody, m.in. Puszczy Kampinoskiej², stanowiącej naturalne bogactwo biosfery: „w lesie są skarby życia, źródła wód i wilgoci..."3.

Opublikowano kilka dzieł Bohdana Dyakowskiego. Między innymi opowiadania przyrodnicze poświęcone problematyce związku natury i kultury. Dyakowski wykorzystał w nich przysłowia, legendy ludowe oraz utwory poetyckie Wincentego Pola, Teofila Lenartowicza, Adama Asnyka ${ }^{4}$. W swoich pracach uwagę poświęcił ochronie owadów, wyjaśniając, że „ochrona owadów pożytecznych stanowi także jeden ze sposobów walki ze szkodnikami, przytem jeden z najdogodniejszych i najpewniejszych..." . Dyakowski określił, że w procesie dydaktyczno-wychowawczym należy nauczyć dzieci odróżniać ptaki pożyteczne od szkodliwych oraz wpoić szacunek dla ptasich gniazd wraz z troską o dokarmianie ptaków zimą ${ }^{6}$. Poza tym Dyakowski przypomniał, że łowiectwo jest elementem kultury polskiej: „zamiłowanie do łowów było u nas powszechne. Polowało rycerstwo i szlachta w ogóle dla samej przyjemności łowów, polowały niższe stany przeważnie dla zysku" W. Wydano także podręcznik z przyrody przeznaczony dla "dwu (albo trzech) niższych klas szkół średnich"8, w którym Dyakowski zaznaczył, że w klasie pierwszej niezbędny jest systematyczny i bezpośredni kontakt uczniów ze środowiskiem przyrody, dzięki któremu dzieci mogą poznać wzajemne zależności poszczególnych bytów w ekosystemie ogrodu, łąki, lasu ${ }^{9}$.

Dyakowski cenił uczenie się na podstawie bezpośrednich obserwacji środowiska życia, zwłaszcza zwierząt udomowionych, żyjących w siedliskach ludzkich. Szczególną uwagę poświęcił koniowi - towarzyszowi i nieocenionemu pomocnikowi człowieka ${ }^{10}$. Stwierdził, że chociaż koń jest wiernym i bardzo pożytecznym

2 Por. K. Chmielewski, Obrazy ziem polskich. Książka przejrzana przez Sekcję gieograficzną Stowarzyszenia Nauczycielstwa Polskiego. Wydawnictwo M. Arcta, Warszawa 1908, s. 230 i nast.

${ }^{3}$ K. Chmielewski, „Twoje ziemie... twoje wody...”. Szkice malownicze z kraju. Wydawnictwo Michała Arcta, Warszawa 1907, s. 79.

${ }^{4}$ Por. B. Dyakowski, Z naszej przyrody. Obrazy z życia zwierząt i roślin krajowych. Wydanie trzecie z 24-ma chromolitografowanemi tablicami i 235-ma rycinami w tekście. Wydawnictwo M. Arcta, Warszawa 1915, s. 1.

${ }^{5}$ B. Dyakowski, Wskazówki do hodowli motyli oraz urządzania zbiorów z 17 rysunkami. Nakładem i drukiem M. Arcta, Warszawa 1906, s. 28. Por. tenże, Historja naturalna. Kurs niższy ułożony podług zbiorowisk. Część pierwsza z rycinami. Wydanie czternaste. Wydawnictwo M. Arcta, Warszawa 1925, s. 42.

${ }^{6}$ Por. B. Dyakowski, Ptaki pożyteczne naszych lasów, pól i ogrodów. 43 ptaki i ich jaja na 25 tablicach kolorowych. Nakładem M. Arcta, Warszawa 1905, s. 3.

7 B. Dyakowski, O dawnych łowach i dawnej zwierzynie, z ilustracjami W. Nowiny-Przybylskiego. Wydawnictwo M. Arcta, Warszawa 1925, s. 9.

${ }^{8}$ B. Dyakowski, Historja naturalna. Kurs niższy ułożony podług zbiorowisk. Część pierwsza z rycinami. Wydanie czternaste. Wydawnictwo M. Arcta, Warszawa 1925, s. 3.

${ }^{9}$ Por. tamże, s. 4.

${ }^{10}$ Por. B. Dyakowski, Wozy, pojazdy i dawne zaprzęgi z czterema rysunkami („Zajmujące Czytanki”, nr 262, z. 2). Wydawnictwo M. Arcta, Warszawa 1918, s. 62. Por. tenże, Dawne drogi i dawne podróże, z jednym rysunkiem („Zajmujące Czytanki”, nr 263, z. 3). Wydawnictwo M. Arcta, Warszawa 1918, s. 144. Por. tenże, Koń bojowy: różne rasy i sposób jeżdżenia. Część druga Koń na wojnie. Wydawnictwo M. Arcta, Warszawa 1900, s. 172. 
współpracownikiem ludzi, jest - zwłaszcza na wsi - źle traktowany, niedostatecznie karmiony. W opowiadaniach dla dzieci wydanych przez Wydawnictwo M. Arcta, Dyakowski promował postawy ekologiczne wobec wszystkich istot żywych ${ }^{11}$ w systemie przyrody. Był zwolennikiem korzystania podczas lekcji szkolnych z niemieckich atlasów, które przygotował do użytku szkolnego dla polskich dzie$\mathrm{ci}^{12}$. W jednym ze swoich dzieł zacytował ekologiczną refleksję Wincentego Pola:

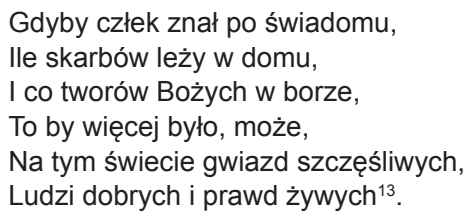

Wydawnictwo M. Arcta wydało również książkę poświęconą problematyce fizjologii roślin, napisaną przez Adama Czartkowskiego, którą opracował z myślą o uczniach szkół średnich ogólnokształcących, co podkreślił, celem „podniesienia wykładu nauk przyrodniczych w naszych szkołach"14. Czartkowski również w innych swoich książkach eksponował wartość nauk przyrodniczych w procesie zdobywania wiedzy. Uogólnił, że przyroda jest nauczycielką życia (magistra vitae), zalecał więc bezpośredni kontakt z przyrodą, uczenie się od przyrody m.in. podczas zajęć w ogrodzie, na polu, w lesie ${ }^{15}$.

Większość książek przyrodniczych napisanych dla dzieci przez Marię Arct-Golczewską opublikowano w przedmiotowym wydawnictwie jeszcze przed odzyskaniem niepodległości w 1918 roku. Niektóre z dzieł zostały uzupełnione przez Januarego i Tadeusza Kołodziejczyków i funkcjonowały w praktyce edukacyjnej w okresie Drugiej Rzeczypospolitej. Przykład stanowi podręcznik do nauki

11 Por. B. Dyakowski, Wąż Władka, opowiadanie z rysunkami. Wydanie drugie. Wydawnictwo M. Arcta, Warszawa 1928, s. 29, 59, 97. Por. tenże, Przygody młodej kawki oraz inne opowiadania przyrodnicze, z licznemi rysunkami Molly Bukowskiej. Wydawnictwo M. Arcta, Warszawa 1928, s. 7, 56-57, 81, 95, 106, 140.

12 Takich jak np.: A. Arends, Atlas historii naturalnej (zoologia, botanika, mineralogia, gieologja) dla użytku szkolonego ułożony (76 tablic, zawierających 1100 wizerunków, tekst objaśniający podług szóstego wydania niemieckiego napisali B. Dyakowski i A. Ślósarski). Nakładem Michała Arcta, Warszawa 1900, s. 1 i nast. Por. K. Lampert, Atlas państwa zwierzęcego. Zwierzęta ssące - ptaki - gady - płazy - ryby - zwierzęta bezkręgowe. 819 wielobarwnych rycin na 96 tablicach, 316 stron tekstu ze 162 drzeworytami. Opracował Bohdan Dyakowski. Wydawnictwo M. Arcta w Warszawie. Część 1-3, Warszawa 1925, passim.

${ }^{13}$ B. Dyakowski, Z naszej przyrody. Obrazy z życia zwierząt i roślin krajowych. Wydanie trzecie z 24-ma chromolitografowanemi tablicami i 235-ma rysunkami w tekście. Wydawnictwo M. Arcta, Warszawa 1915, s. 6.

${ }^{14}$ A. Czartkowski, Doświadczenia z fizjologii roślin. Wydawnictwo M. Arcta, Warszawa 1910, s. 7.

15 Por. A. Czartkowski, Ćwiczenia z anatomii roślin. I. Tekst. Wydanie trzecie przejrzane. Wydawnictwo M. Arcta, Warszawa 1928, s. 4, 9, 13 i nast. Por. tenże, Ćwiczenia z anatomji roślin. I. Tekst. Wydanie drugie przejrzane. Wydawnictwo M. Arcta, Warszawa-Poznań-Lwów-Równe-Lublin-ŁódźWilno 1922, passim. Por. tenże, Ćwiczenia z anatomji roślin. II. Atlas, 102 rysunki na 31 tablicach. Wydawnictwo M. Arcta, Warszawa 1928, ss. 31. 
botaniki ${ }^{16}$, który służył dydaktyczną pomocą w procesie poznawania roślin, ich budowy, odżywiania, oddychania itp. W siódmym wydaniu tego podręcznika (1923), w ostatniej jego części omówiono problematykę związaną z ingerencją człowieka w środowisko życia (roślinność pierwotna, puszcze, stepy, które człowiek przemienił na urodzajne pola, rozpowszechnił rośliny obce polskiej florze). W podręczniku zaznaczono, że wyjątek stanowią Góry Świętokrzyskie, Karpaty, Tatry, Puszcza Białowieska - naturalne obszary, w których zachowała się pierwotna szata roślinna, partie leśne: „szczątki te winny być zachowane przez nas, jako żywe pomniki pierwotnej przyrody"17. Pomimo że podręcznik był stopniowo zmieniany, uzupełniany i dostosowywany do najnowszych osiągnięć naukowych i pedagogicznych, również w zakresie wychowania ekologicznego, ochrony przyrody, systematycznie był publikowany w Wydawnictwie M. Arcta ${ }^{18}$. W jego jedenastym wydaniu (1929), oprócz wiedzy o ekosystemie Puszczy Białowieskiej, przyrodzie w Tatrach, Pieninach, Karpatach Wschodnich (Czarnohora), Karpatach Zachodnich, umieszczono cenne ze względów dydaktyczno-wychowawczych treści kształcenia, poświęcone ochronie szarotki w Tatrach, mikołajka nadmorskiego nad Morzem Bałtyckim oraz ochronie cisów, modrzewia i innych ginących roślin ${ }^{19}$. Omawianą publikację ubogacono fotografią sosnowego boru w Puszczy Białowieskiej ${ }^{20}$.

Wydawnictwo M. Arcta wydało również inne dzieła przyrodnicze dla dzieci, napisane przez M. Arct-Golczewską, poświęcone wiedzy o roślinach ${ }^{21}$. Przykład

${ }^{16}$ Por. M. Arct-Golczewska, Podręcznik do nauki botaniki, część pierwsza i druga razem. Wydanie czwarte zmienione i poprawione przez J. i T. Kołodziejczyków z 339-ma rycinami. Wydawnictwo M. Arcta, Warszawa 1918, s. 7. Por. M. Arct-Golczewska, Podręcznik do nauki botaniki, część pierwsza i druga razem. Wydanie piąte zmienione i poprawione przez J. i T. Kołodziejczyków, z 339-ma rycinami. Wydawnictwo M. Arcta, Warszawa 1920, s. 8. Por. M. Arct-Golczewska, Podręcznik do nauki botaniki, opracowali podług nowego programu January i Tadeusz Kołodziejczykowie. Część pierwsza. Wydanie szóste. M. Arct, Warszawa 1922, s. 1, 9, 15, 50, 84 i nast.

17 M. Arct-Golczewska, Podręcznik do nauki botaniki, opracowali January i Tadeusz Kołodziejczykowie. Wydanie siódme poprawione, z 336 rysunkami i 8 tablicami. Dozwolone przez Ministerstwo WRiOP do użytku w szkołach średnich. Wydawnictwo M. Arcta, Warszawa 1923, s. 218.

${ }_{18}$ Por. M. Arct-Golczewska, J. i T. Kołodziejczykowie, Podręcznik do nauki botaniki. Wydanie ósme poprawione, z 358 rysunkami i 8 tablicami. Wydawnictwo M. Arcta, Warszawa 1924, s. 1. Por. M. Arct-Golczewska, J. i T. Kołodziejczykowie, Podręcznik botaniki. Wydanie dziewiąte uzupełnione i poprawione, z 339 rysunkami w tekście i 4 tablicami. Wydawnictwo M. Arcta, Warszawa 1925, s. 296. Por. M. Arct-Golczewska, J. i T. Kołodziejczykowie, Podręcznik botaniki. Wydanie dziesiąte uzupełnione i poprawione, z 327 rysunkami i 4 tablicami. Wydawnictwo M. Arcta, Warszawa 1927, s. 302.

${ }_{19}$ Por. M. Arct-Golczewska, J. i T. Kołodziejczykowie, Podręcznik botaniki. Wydanie jedenaste uzupełnione i poprawione, z 320 rysunkami. Wydawnictwo M. Arcta, Warszawa 1929, s. 303.

${ }^{20}$ Tamże, s. 1, 303. Por. M. Arct-Golczewska, J. i T. Kołodziejczykowie, Podręcznik botaniki. Wydanie dwunaste uzupełnione i poprawione, z 320 rysunkami. Wydawnictwo M. Arcta, Warszawa 1930, s. 1.

${ }^{21}$ Por. M. Arct-Golczewska, Botanika na przechadzce, 16 tablic kolorowych, 212 rysunków roślin z tekstem objaśniającym (plus album roślin). Część pierwsza. Wydanie trzecie. Wydawnictwo M. Arcta, Warszawa 1929, ss. 26. Por. M. Arct-Golczewska, Botanika na przechadzce, 208 rysunków na 20 tablicach. Wydanie trzecie z tekstem objaśniającym, przejrzanym i uzupełnionym przez dr. J. Kołodziejczyka (plus album). Część druga. Wydawnictwo M. Arcta, Warszawa 1929, ss. 40. 
stanowi atlas roślin ${ }^{22}$ oraz album o kwiatach letnich i jesiennych ${ }^{23}$, a także opowiadanie pt. Mali przyrodnicy, które uwrażliwia dzieci na wartość estetyczną i wartość utylitarną pożytecznych dla człowieka roślin, drzew, warzyw ${ }^{24}$. Poza tym w Wydawnictwie M. Arcta wydano przetłumaczone na język polski książki dla dzieci zagranicznych autorów, między innymi pogadanki A. B. Buckley, które opracowała do użytku szkolnego dla polskich dzieci Maria Arct-Golczewska. Prezentują wiedzę o drzewach, ich walorach estetycznych, ekologicznych, zdrowotnych, utylitarnych ${ }^{25}$, zachęcają młodych czytelników do poznawania środowiska przyrody oraz wzajemnej zależności organizmów w środowisku ich życia ${ }^{26}$. Problematyka ekologiczna zaistniała również w przetłumaczonych na język polski przez Marię Arct-Golczewską pogadankach przyrodniczych, które stosowano w działalności dydaktyczno-wychowawczej w formie „czytanek dopełniających”, opublikowanych w ramach serii wydawniczej pt. „Zwróć Oczy na Przyrodę"27.

Wydano także opracowane przez Marię Arct-Golczewską, na podstawie podręczników w języku angielskim K. G. Lutz'a, wskazówki pomocne w zbieraniu, określaniu, zasuszaniu roślin i układaniu zielników - w celu poznania roślinności środowiska lokalnego ${ }^{28}$. Poza tym opublikowano przetłumaczone i opracowane przez Marię Arct-Golczewską opowiadania przyrodnicze H. Coupina, dzięki którym polskie dzieci poznawały życie małp, gibbonów, psów, górskich kozic, kotów, fok, ryb oraz ropuch ${ }^{29}$. Dobry przykład w tym zakresie stanowią również przetłumaczone przez Arct-Golczewską na język polski opowiadania przyrodnicze E. Thompsona o życiu ptaków i zwierząt ${ }^{30}$ oraz opowiadania C. Floericke o życiu

22 M. Arct-Golczewska, Atlas roślin krajowych (botanika na przechadzce), 208 rysunków roślin na 20 tablicach (plus atlas). Wydanie czwarte, z tekstem objaśniającym, przejrzanym i uzupełnionym przez dr. J. Kołodziejczyka. Wydawnictwo M. Arcta, Warszawa 1938, ss. 46.

23 Zob. M. Arct-Golczewska, Kwiaty letnie i jesienne. Wydawnictwo M. Arcta, Warszawa 1934.

24 Por. M. Arct-Golczewska, Mali przyrodnicy. Wydanie drugie, z rycinami (Seria „Moje Książeczki”, nr 98). Wydawnictwo M. Arcta, Warszawa 1917, ss. 44.

25 Por. A. B. Buckley, Drzewa i krzewy, podług angielskiego oryginału opracowała Maria Arct-Golczewska, z 8 tablicami barwnemi i 42 rysunkami w tekście (Seria „Zwróć Uwagę na Przyrodę”, Książeczka 6). Wydawnictwo M. Arcta, Warszawa 1909, s. 5-8, 27, 57, 76.

${ }^{26}$ Por. A. B. Buckley, Życie w lesie i w polu, „Zwróć Oczy na Przyrodę”, Książeczka trzecia, opracowała podług angielskiego Maria Arct-Golczewska z 8 tablicami barwnemi i 28 rysunkami w tekście. Wydawnictwo M. Arcta, Warszawa 1908, s. 5, 8, 12, 16, 25, 29, 47, 51, 55, 61 i nast.

27 Por. A. B. Buckley, Życie roślin w polu, na łące $i$ w ogrodzie, opracowane przez Marię Arct-Golczewską. Wydanie drugie z 8-ma tablicami barwnemi i 35-ma rysunkami w tekście („Zwróć Oczy na Przyrodę", 1). Wydawnictwo M. Arcta, Warszawa 1919, s. 3-4, 7-8 i nast.

28 Por. M. Arctówna, Wskazówki do zbierania, określania, zasuszania roślin i układania zielnika, według podręczników dra K. G. Lutz’a i innych z 75-ma rysunkami (Seria „Książki dla Wszystkich”, nr 205). Wydawnictwo M. Arcta, Warszawa 1905, s. 4.

29 Por. H. Coupin, Zwierzęta gimnastykujące się, z 17 rysunkami („Zajmujące Czytanki Przyrodnicze"), opracowane przez Marię Arct-Golczewską. Wydawnictwo M. Arcta, Warszawa 1900, s. 3, 6, 8-11, 18-19, 23, 28.

${ }^{30}$ E. Thompson, Nowe opowiadania z życia zwierząt „Śpiewak uliczny przygody wróbla Grzmotka” (Seria 5 „Zajmujące Czytanki Przyrodnicze”, nr 6), przetłumaczone z j. angielskiego przez Marię Arct-Golczewską. Wydawnictwo M. Arcta, Warszawa b. r. w., s. 23. Por. tenże, Nowe opowiadanie z życia zwierząt. II. Wully Pies owczarski (Seria 5 „Zajmujące Czytanki Przyrodnicze”, 4), przetłumaczone przez Marię Arct-Golczewską. Wydawnictwo M. Arcta, Warszawa 1909, s. 3 i nast. 
skowronka, kobuza, gąsiorka, wrony, gawrona, kuropatwy, przepiórki, wilgi, pustułki, myszołowa, jastrzębia oraz zająca, jeża, kreta, łasicy, myszy polnej, chomika, jaszczurki, padalca, koników polnych i świetlików ${ }^{31}$. Wydawnictwo M. Arcta wydało także przetłumaczoną na język polski z języka francuskiego przez Marię Arct-Golczewską książkę dla nauczycieli, napisaną przez P. Ledoux’a, w której podkreślono wartość wody, jej życiodajne znaczenie dla życia w biosferze oraz wartość roślin pokarmowych ${ }^{32}$, drzew i poszycia leśnego ${ }^{33}$.

Wanda Haberkantówna w swoich publikacjach przekazywała wiedzę o środowisku naturalnym. Akcentowała jego wartość w prawidłowym rozwoju człowieka, zwłaszcza czystego powietrza, drzew i roślin, które korzystnie wpływają na istoty ludzkie, również ze względu na walor estetyczny. Kilka z jej dzieł poświęconych wycieczkom wydano w Wydawnictwie M. Arcta ${ }^{34}$. Podobnie zresztą jak opowiadania przyrodnicze dla dzieci napisane przez G. G. Lewisa, które przetłumaczono na język polski i dostosowano do użytku szkolnego w okresie Drugiej Rzeczypospolitej, dzięki zaangażowaniu Wandy Haberkantówny ${ }^{35}$.

Wydano dzienniczki przyrodnicze Delfiny Gayówny, służące jako materiał metodyczny z przyrodoznawstwa. Zawierają szczegółowy opis zakwitania wiosennej flory, opis wiosennej burzy. Wyjaśniają znaczenie wody dla życia w środowisku przyrody oraz proces dojrzewania żyta, owoców (także leśnych), warzyww ${ }^{36}$, a także zmiany zachodzące w środowisku przyrody w poszczególnych porach roku, implikują ponadto opis roślin i zwierząt w ogrodzie miejskim i na wsi ${ }^{37}$. Opublikowano również podręcznik z geografii dla szkół powszechnych napisany przez Delfinę Gayównę. W pierwszym roku nauczania tego przedmiotu treść kształcenia związana była przede wszystkim z poznawaniem rodzinnej wsi lub miasta. Są w tym podręczniku informacje o bogactwach naturalnych, zdjęcia gór (wraz z górską roślinnością i zwierzętami), dolin ${ }^{38}$.

W Wydawnictwie M. Arcta wydano drukiem opowiadania przyrodnicze dla dzieci napisane w warunkach niewoli narodowej przez Bronisława Gustawicza

31 Por. C. Floericke, Młodzi przyrodnicy. Wycieczki zoologiczne (według oryginału napisała Maria Arct-Golczewska), książka II. W polu i na łące, z 3 tablicami barwnemi i licznemi rycinami. Druk M. Arcta, Warszawa 1912, s. 5-117.

32 Por. P. Ledoux, 50 lekcyj przygotowawczych z nauk przyrodniczych. Część pierwsza: Najprostsze wiadomości o ciałach, z 72 rysunkami (tłum. M. Arct-Golczewska). Wydanie drugie. Wydawnictwo M. Arcta, Warszawa 1916, s. 4, 64, 66.

33 Por. P. Ledoux, 50 lekcyj przygotowawczych z nauk przyrodniczych. Część druga: Ziemia uprawna i świat roślinny. Wydanie drugie, z 70 rysunkami (tłum. Maria Arct-Golczewska). Wydawnictwo M. Arcta, Warszawa 1918, 123.

34 Por. W. Haberkantówna, Z naszych wycieczek, z 39 rycinami. Wydawnictwo M. Arcta, Warszawa 1918, passim. Por. taż, Z naszych wycieczek, z 53 rycinami. Wydanie drugie, Wydawnictwo M. Arcta, Warszawa 1925, s. 66 i nast.

35 G. G. Lewis, Program propedeutyki przyrody oraz wskazówki jak należy go przeprowadzić (tłum. Z. Wołowska, słowo wstępne K. Chmielewski). Wydawnictwo M. Arcta, Warszawa 1918, s. 11.

${ }^{36}$ Por. D. Gayówna, Dzienniczki przyrodnicze. Przyczynek do metodyki przyrodoznawstwa z rysunkami. Wydawnictwo M. Arcta, Warszawa 1918, s. 14.

37 Por. tamże, s. 16, 26.

38 Por. D. Gayówna, Geografja. Krajoznawstwo. Wydanie nowe dziesiąte. Wydawnictwo M. Arcta, Warszawa 1922, s. 3, 41-43. 
i Edmunda Wyrobka. Zawierają opisy przyrody w poszczególnych porach roku ${ }^{39}$. Były stosowane w praktyce dydaktyczno-wychowawczej w szkołach ogólnokształcących w okresie Drugiej Rzeczypospolitej. Podobnie zresztą jak pogadanki przyrodnicze napisane przez Mieczysława Brzezińskiego, które implikują treść kształcenia dotyczącą życia wielu gatunków zwierząt oraz o naturalnych darach przyrody, które są wykorzystywane w przemyśle farmaceutycznym ${ }^{40}$.

Ekologiczno-wychowawcze treści kształcenia występują w twórczości Aleksandra Janowskiego. Kilka z jego książek poświęconych znaczeniu wycieczek krajoznawczych w procesie dydaktyczno-wychowawczym wydano w Wydawnictwie M. Arcta. Należy zaznaczyć, że Janowski zwracał uwagę swoich czytelników na naturalne bogactwa Polski, takie jak m.in. morze, bursztyn, lasy ${ }^{41}$ - łącząc treści krajoznawcze z wychowaniem patriotycznym, promowaniem walorów piękna ojczystej przyrody 42 .

Należy dodać, że opublikowano przewodnik krajoznawczy napisany przez Tadeusza Dybczyńskiego jeszcze przed odrodzeniem się Rzeczypospolitej w 1918 roku. Dzieło zawiera opisy flory i fauny, implikuje ekologiczno-wychowawczą treść kształcenia, wyjaśniającą wartość poznawania środowiska życia oraz ochraniania przyrody przed zniszczeniem, jej unicestwieniem ${ }^{43}$. Dybczyński w opowiadaniach przyrodniczych akcentował znaczenie harmonijnego współżycia z przyrodą ${ }^{44}$. W swoich publikacjach wyraził zachwyt dla naturalnego piękna Puszczy Świętokrzyskiej wraz z ekologiczną troską o ochranianie żyjących na jej obszarze rzadkich gatunków roślin i zwierząt ${ }^{45}$. Podkreślił walor leczniczy naturalnych wód mineralnych na ziemiach polskich oraz znaczenie złóż naturalnych, takich jak m.in. węgiel kamienny i brunatny, rudy żelaza, miedzi ${ }^{46}$.

Jak już wspomniano, w Wydawnictwie M. Arcta wydawano drukiem przetłumaczone na język polski dzieła zagranicznych autorów, które stosowano w praktyce edukacyjnej w okresie Drugiej Rzeczypospolitej, między innymi przetłumaczoną pod kierunkiem Wacława Jezierskiego pracę A. Schleyera poświęconą problematyce życia ryb, płazów, gadów oraz ich znaczenia dla życia

${ }^{39}$ B. Gustawicz, E. Wyrobek, Wśród dolin i gór. Przechadzki przyrodnicze, ozdobione i objaśnione w tekście barwnemi 152 rycinami. Wydawnictwo M. Arcta, Warszawa 1914, s. 78, 148, 192.

40 Por. M. Brzeziński, Pogadanki z dziedziny przyrody i przemysłu część pierwsza i druga. Pośród zwierząt i roślin. Wydanie ósme przejrzane i dopełnione przez Władysława Umińskiego wieloma rysunkami. Wydawnictwo M. Arcta, Warszawa 1925, s. 245 i nast.

41 Por. A. Janowski, Nad polskim morzem, z 12 rysunkami, Staraniem Polskiego Towarzystwa Krajoznawczego. Wydawnictwo M. Arcta, Warszawa 1919, s. 41.

42 Por. A. Janowski, Nasza ojczyzna. Wydawnictwo M. Arcta, Warszawa 1919, s. 28-29, 44.

43 Por. T. Dybczyński, Przewodnik po Górach Świętokrzyskich (Łysogórach). Wydawnictwo i druk M. Arcta, Warszawa 1912, s. 34.

${ }_{44}$ Por. T. Dybczyński, Spis opowiadań na tle przyrody oraz spis opowiadań przyrodniczych, [w:] tenże, Z teki turysty. Opis 88-o milowej pieszej podróży po kraju. Wydawnictwo M. Arcta, Warszawa 1909 , s. 165.

45 Por. T. Dybczyński, Tania podróż po kraju. Zajmujący opis pieszej podróży, z licznemi rycinami. Nakładem M. Arcta, Warszawa 1911, s. 11. Por. tenże, Góry Świętokrzyskie (Staraniem Polskiego Towarzystwa Krajoznawczego). Wydawnictwo M. Arcta, Warszawa 1919, s. 55.

46 Por. T. Dybczyński, Skarby kopalne ziem polskich, Staraniem Polskiego Towarzystwa Krajoznawczego. Wydawnictwo M. Arcta, Warszawa 1919, s. 6, 16, 30, 36, 38, 43, 46, 48, 52, 58. 
człowieka ${ }^{47}$. Wydano również przetłumaczony z języka angielskiego na język polski program propedeutyki przyrody, który opracował G. G. Lewis. Autor uzasadnił znaczenie bezpośredniego kontaktu z przyrodą w procesie dydaktyczno-wychowawczym, konieczność eksploracji przyrodniczych, nie tylko na lekcjach z przyrody, ale również na lekcjach z rysunku, modelowania, geografii, poezji i muzyki, co ważne $-\mathrm{z}$ zamiłowaniem ${ }^{48}$.

Opublikowano ponadto skróconą wersję opowiadania napisanego przez K. Hagenbecka o zwierzętach żyjących w parku zoologicznym w Stellingen koło Hamburga ${ }^{49}$. Opowiadanie stanowi piękną ekspresję twórczą o miłości do zwierząt, uwrażliwia dzieci na ogromne znaczenie postawy szacunku względem zwierząt, stworzenia im dobrych warunków egzystencji - zwłaszcza podczas choroby. Opowiadanie wydano ponownie w 1928 roku $^{50}$. W Wydawnictwie M. Arcta opublikowano również przetłumaczone z języka niemieckiego na język polski książki A. E. Brehma, uwrażliwiające dzieci na problem złego traktowania zwierząt, braku dostatecznej troski o dobre warunki życia ptaków (wycinanie lasów) ${ }^{51}$.

$\mathrm{Na}$ podstawie celowo zaprezentowanych przykładów można stwierdzić, że w Wydawnictwie M. Arcta, które po śmierci Michała Arcta (1840-1916) funkcjonowało pod zarządem jego synów - Zygmunta i Stanisława Jana, opublikowano książki szkolne o problematyce przyrodniczej i krajoznawczej, które stosowano w praktyce dydaktyczno-wychowawczej w szkołach powszechnych i średnich ogólnokształcących w okresie Drugiej Rzeczypospolitej, w których hasłowo ujęto treść kształcenia w zakresie edukacji ekologicznej. Są to programy nauczania, podręczniki z przyrody/botaniki, geografii, opowiadania o życiu zwierząt, pogadanki przyrodnicze i krajoznawcze, czytanki przyrodnicze, atlasy przyrodnicze, szkice artystyczne poświęcone przyrodzie (naturze), ćwiczenia z botaniki, wskazówki praktyczne, przewodniki krajoznawcze, tłumaczenia książek zagranicznych autorów - opracowane do użytku szkolnego w szkołach powszechnych i średnich ogólnokształcących. Należy dodać, że problematyka edukacji ekologicznej zaistniała w wielu książkach szkolnych wydanych również w innych wydawnictwach, takich jak m.in.: Książnica Polska Towarzystwa Nauczycieli Szkół Wyższych we Lwowie, Wydawnictwo Oświata Towarzystwa Nauczycieli Szkół Wyższych w Warszawie, Wydawnictwo Naszej Księgarni w Warszawie, Gebethner i Wolff w Warszawie, Książnica-Atlas (Lwów-Warszawa), Państwowe Wydawnictwo Książek Szkolnych we Lwowie.

47 A. Schleyer, Ryby, płazy, gady, atlas 30 tablic barwnych o 226 wizerunkach z tekstem (tłum. I. Milewska, pod kierunkiem W. Jezierskiego). Wydawnictwo M. Arcta, Warszawa 1914, s. 5, 9, 46, 55, 62, 79, 85-86, 88.

${ }^{48}$ Por. G. G. Lewis, „Program propedeutyki przyrody” oraz wskazówki jak należy go przeprowadzić (tłum. Z. Wołowska, słowo wstępne K. Chmielewski). Wydawnictwo M. Arcta, Warszawa 1918, s. 7, 9, 15-16.

${ }^{49} \mathrm{~K}$. Hagenbeck, Z życia zwierząt w niewoli, streściła Jadwiga Bornstein (z 40 rysunkami). Wydawnictwo M. Arcta, Warszawa 1910, s. 1-131.

${ }^{50}$ Według Karola Hagenbecka opowiedziała Jadwiga Bornsteinowa, Z życia zwierząt w niewoli. Wydanie drugie z 39 rysunkami. Wydawnictwo M. Arcta, Warszawa 1928, s. 35.

${ }^{51}$ A. E. Brehm, Z życia zwierzat, I. Zwierzęta ssące, przełożyła M. A. Nakładem i drukiem M. Arcta, Warszawa 1901, s. 65, 67. Por. tenże, Z życia zwierząt, II. Ptaki, przełożyła M. A. Nakładem i drukiem M. Arcta, Warszawa 1902, s. 82. 